\title{
MORPHOMETRIC CHARACTERIZATION OF THE HYDROGRAPHIC BASIN OF JAUQUARA RIVER IN THE TRANSITION BETWEEN THE CERRADO AND AMAZON BIOMES IN MATO GROSSO-BRAZIL
}

\author{
Gabriel Americo Cassettari ${ }^{*}$, Tadeu Miranda de Queiroz ${ }^{2}$ \\ 1 *Mato Grosso State University (UNEMAT), Department of Agroindustrial Production Engineering, Barra do Bugres, Mato \\ Grosso, Brazil - gabriel.cassettari@unemat.br \\ ${ }^{2}$ University of the State of Mato Grosso (UNEMAT), Graduate Program in Environment and Agricultural Production Systems, \\ Barra do Bugres, Mato Grosso, Brazil - tdmqueiroz@unemat.br
}

Received for publication: 28/02/2018 Accepted for publication: 19/11/2018

\begin{abstract}
This study aimed to perform the Jauquara river watershed morphometric characterization. To watershed delimitation was used SRTM 30 type Digital Elevation Model (Shuttle Radar Topography Mission, with spatial resolution of $30 \mathrm{~m}$ ) provided by USGS Earth Explorer platform. The geographic information system used to watershed delimitation process and maps generation was ArcGIS 10.1 from ESRI ${ }^{\circledR}$. The morphometric variables calculus was based on classic methodologies of Applied Hydrology. The watershed has an area of $1408,03 \mathrm{~km} 2$ and perimeter of $288,43 \mathrm{~km}$ with compactness coefficient and circularity index of $\mathrm{Kc}=2.15$ and Ic $=0.21$, respectively, which show an elongated shape. The drainage was classified as 5 th order, reinforcing the configuration of the drainage network with a wide hydric distribution. The predominant altitude range is between 368 and $552 \mathrm{~m}$, which corresponds to an area of $478.10 \mathrm{~km}^{2}$. It was observed that there is a predominance of smooth-wavy and undulated reliefs (3-8\%, 8-20\% slope), which correspond to $38,05 \%$ and $23,04 \%$ of the total basin area respectively. The morphometric characterization of the basin made it possible to obtain unpublished information that contributes to the decision making regarding the effective water management in the studied area, being this a guiding study for other works.
\end{abstract}

Keywords: hydrography; hydrology; water resource.

\section{Resumo}

Caracterização morfométrica da bacia hidrográfica do rio Jauquara, na transição entre os biomas cerrado e amazônia, em Mato Grosso- Brasil Este trabalho teve como objetivo realizar a caracterização morfométrica da bacia hidrográfica do rio Jauquara. Para delimitação, foi utilizado o Modelo Digital de Elevação do tipo SRTM 30 (Shuttle Radar Topography Mission, com resolução espacial de $30 \mathrm{~m}$ ) fornecido pela plataforma USGSEarth Explorer. O Sistema de Informação Geográfica (GIS) utilizado para os processos de delimitação automática da bacia hidrográfica e geração de mapas foi o ArcGIS 10.1 da ESRI ${ }^{\circledR} \mathrm{O}$ cálculo das variáveis morfométricas foi feito com base nas metodologias da hidrologia aplicada. A bacia possui área de $1408,03 \mathrm{~km}^{2}$ e perímetro de $288,43 \mathrm{~km}$, com coeficiente de compacidade e índice de circularidade em 2,15 e 0,21, respectivamente, os quais evidenciam formato alongado. A rede de drenagem foi classificada como de $5^{\text {a }}$ ordem, reforçando a configuração da rede de drenagem com vasta distribuição hídrica. A classe de altitude predominante está entre 368 e $552 \mathrm{~m}$, a qual corresponde a uma área de $478,10 \mathrm{~km}^{2}$. Observou-se que há predominância dos relevos suave-ondulado e ondulado (3-8\%, 8-20\% de declividade), que correspondem à 38,05\% e 23,04\% da área total da bacia, respectivamente. A caracterização morfométrica da bacia possibilitou a obtenção de informações inéditas que contribuem para a tomada de decisão no que diz respeito à gestão hídrica efetiva na área estudada, sendo este um estudo norteador para outros trabalhos.

Palavras-chave: hidrografia; hidrologia; recurso hídrico.

\section{INTRODUCTION}

Water has a fundamental role and several purposes, such as domestic supply, agriculture, power generation, recreation, fishing and navigation. It is an integral part of the environment, it is among many vital biological processes and encompasses numerous ecosystems and ecological niches. The hydrological cycle consists of several processes and physical-chemical reactions in which the water leaves an initial stage and returns to the primitive state, from the solar radiation, evapotranspiration and evaporation (BACCI; PATACA, 2008).

Demographic growth and industrial expansion, coupled with a lack of planning and management, are evidence of day-to-day scarcity of water resources. As an example, it is mentioned the emptying of the Cantareira System, responsible for supplying the metropolitan region of São Paulo, which is a system composed of reservoirs, canals and pumps that supplies the region since the 1970s, however since the authorization of its use aspects like the increase of hidric demand over time were not considered and today the population feels the effects of lack of management in terms of supply (KELMAN, 2015). 
The geoprocessing tools come towards helping this problem for the delimitation of areas for conservation of natural resources (ENCINAS et al., 2012). The growth of the capacity of processing and storage of databases in computers together with the continuous advancement of the Geographic Information Systems (GIS) makes possible an improvement of geomorphological studies (GROHMANN et al., 2008).

Among these data, the numerical grid called the digital elevation model / numerical terrain model (DEM / MNT) is constituted by information regarding the spatial distribution of the altitude and surface of the terrain that allow the calculation of the morphometric variables with precision (GROHMANN et al., 1976).

In this way, georeferenced digital maps provide support for the detection and resolution of problems of various natures, helping in decision making (SOBRINHO et al., 2010).

Considering the watershed as an integrated planning unit that involves the balance between human activities, climate (external factors), fauna, flora (internal factors) (PORTO, PORTO, 2008), morphometric characterization studies, involving the quantification of parameters (SOARES, SOUZA, 2012). In this study, we present the results of the study of soil and water management in Brazil.

The knowledge of morphometric parameters calculated as shape factor, river density, concentration time, channel gradient, among others, helps the decision maker to follow changes in the hydrographic unit, recurring external and internal factors, and manage their diverse uses to ensure full water availability with quality (GEORGIN et al., 2015).

Lima (2008) also highlights the need to interpret morphometric characteristics so that the hydrological behavior of the watershed can be understood and quantified, phenomena such as surface flow, infiltration, and quantity of water produced with the runoff.

The study of the relief associated with vegetation cover and rainfall regime is important because these aspects are directly related to the dynamics of the surface runoff, which in turn influences the occurrence of floods and degradation of the watersheds (LEAL; TONELLO, 2016).

In this context, the aim of this study is to characterize the Jauquara River Basin (BHRJ) by quantifying morphometric parameters through automatic delimitation of watershed and generation of altimetry and slope maps.

\section{MATERIAL AND METHODS}

This paper is part of the results of a research project that aimed to study water resources in the Jauquara river watershed, for which monthly data collection campaigns were carried out between February 2016 and October 2017, covering both scopes of the whole extension of the river, from its main source to its mouth, in the Paraguay River. In this course, biotic and abiotic parameters were observed: soil type, vegetation, hydrography, pluviometric regime and socioeconomic parameters: infrastructure, economic activities and contact with local residents and their realities.

The study was developed in the Laboratory of Water Quality (LaQuA) of the University of the State of Mato Grosso (UNEMAT), in the Campus of Barra do Bugres, adding to the activities of the Extension Program in interface with the research "BB Água Limpa".

\section{Area of study}

The region of study (Figure 1) presents the following characteristics: annual precipitations varying between 1200 and $2000 \mathrm{~mm}$; two climatic types: (1) warm, semi-humid and temperate savanna tropical (Aw) and (2) warm humid tropical altitude (Cwa), according to the Köppen climatic classification; average temperatures between 22 and $28{ }^{\circ} \mathrm{C}$ (SOUZA et al, 2013). It presents diverse types of soils, among the main ones: sand quartzosas, latosols and cambisols; the predominant vegetation is the woods, Cerrado and Cerrado fields (PESSOA, 2014).

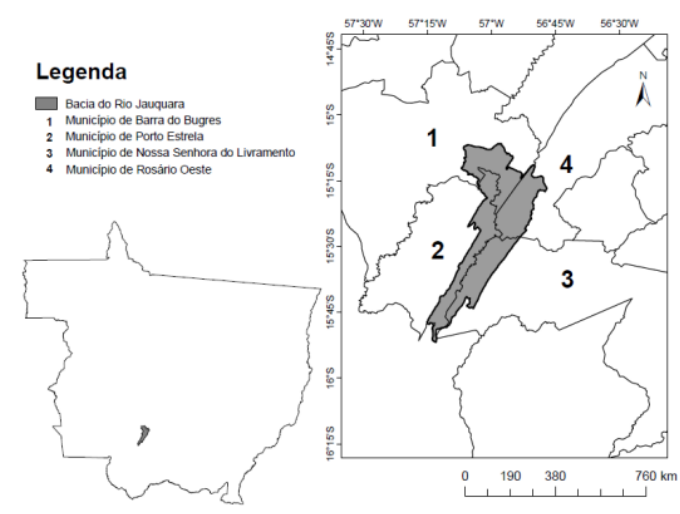

FLORESTA, Curitiba, PR, v. 49, n. 2, p. 325-334, abr/jun 2019 
Figure 1. Format and location of the Jauquara river watershed in the state of Mato Grosso.

Figura 1. Formato e localização da bacia hidrográfica do rio Jauquara no estado de Mato Grosso.

Processing of the digital elevation model (DEM)

It was used the SRTM 30 type DEM (Shuttle Radar Topography Mission, with spatial resolution of 30 m) as provided by the USGS (United States Geological Survey) platform Earth Explorer, some among them reprogramming flat coordinates and setting the raster pixel type to 16-bit integer. The geographic information system (GIS) used for the processes of automatic delimitation of the watershed was ArcGIS 10.1 from ESRI ${ }^{\circledR}$ (Environmental Systems Research Institute).

Delimitation of the hydrographic basin of the Jauquara river

The DEM of the properly configured study area was used as an input for delineation of the watershed through the Arc Hydro Tools extension, a set of tools for hydrological analysis, which were executed sequentially, as described below:

Fill Sinks: The DEM is a numerical matrix of altitudes that may contain faults due to rugged topography in the form of sinks and existence of water bodies (SOBRINHO et al., 2010). Fill Sinks detects these faults and fills them up for more accurate runoff.

Flow Direction: A tool that describes numerically which direction will the water travel in each pixel of the EAW. This step converts the numerical matrix of the DEM into a flow matrix using a numerical code of direction in a pixel with respect to its neighboring pixels.

Flow Acumulation: First representation of hydrography, which gathers flow information.

Stream Definition: Process that generates the final drainage network. In this step it was necessary to test values for the threshold (1000 was used) and overlap the network generated with the DEM in order to evaluate the accuracy of the same.

Altitude, slope and classification of agricultural aptitude of the lands of the Jauquara river watershed.

The same GIS was used to generate the altitude and slope maps and later some morphometric indexes. The contour tool was run in the tool section entitled Raster Surface to create contour lines. From the insertion of the curves in the same section, the slope tool was executed for the relief raster, and in the section 3D Analyst Tools, the tool TIN generated the three-dimensional altimetric raster. The altitude classes were determined automatically in the GIS software and were based only on the digital elevation model. The classes of slope and the classification of the agricultural aptitude of the lands were determined according to the classification of Ramalho Filho and Beek (1995), which is currently adopted by EMBRAPA. An adapted clipping of the classification key was performed, in which the factors susceptibility to erosion and impediments to mechanization are considered subdivided by degrees of limitation, according to Table 1 .

Table 1. Land suitability classification key: parameters and degrees of limitation.

Tabela 1. Chave de classificação de aptidão de terras: parâmetros e graus de limitação.

\begin{tabular}{|c|c|c|c|c|c|c|c|c|c|c|c|c|}
\hline \multirow{3}{*}{ Relief class } & \multirow{3}{*}{$\begin{array}{c}\text { Declivity } \\
\%\end{array}$} & \multicolumn{10}{|c|}{ Degrees of limitation } & \multirow{3}{*}{ Indicated use } \\
\hline & & \multicolumn{5}{|c|}{ Susceptibility to erosion } & \multicolumn{5}{|c|}{$\begin{array}{l}\text { Impediments } \\
\text { mechanization }\end{array}$} & \\
\hline & & $\mathbf{N}$ & $\mathbf{L}$ & $\mathbf{M}$ & $\mathbf{S}$ & VS & $\mathbf{N}$ & $\mathbf{L}$ & M & $\mathbf{S}$ & VS & \\
\hline Plan & $0-3$ & $\mathrm{x}$ & & & & & $\mathrm{x}$ & & & & & Crops \\
\hline Soft-Wavy & $3-8$ & & $\mathrm{x}$ & & & & & $\mathrm{x}$ & & & & Crops \\
\hline Moderately-Wavy & $8-13$ & & & $\mathrm{x}$ & & & & & $\mathrm{X}$ & & & Pasture / Forestry \\
\hline Wavy & $13-20$ & & & & $\mathrm{x}$ & & & & & $\mathrm{x}$ & & Pasture / Forestry \\
\hline Strong-Wavy & $20-45$ & & & & & $\mathrm{x}$ & & & & & $\mathrm{x}$ & Forestry \\
\hline Mountainous & $45-75$ & & & & & $\mathrm{x}$ & & & & & $\mathrm{x}$ & $\begin{array}{c}\text { Preservation of flora and } \\
\text { fauna }\end{array}$ \\
\hline Strong-Mountainous & $>; 75$ & & & & & $\mathrm{x}$ & & & & & $\mathrm{x}$ & $\begin{array}{c}\text { Preservation of flora and } \\
\text { fauna }\end{array}$ \\
\hline
\end{tabular}

\section{Morphometric characterization}

The geoprocessing of data yielded the value of the drainage area $\left(\mathrm{A}\right.$ in $\left.\mathrm{km}^{2}\right)$, perimeter $(\mathrm{P}$ in $\mathrm{km})$, number of watercourses $(\mathrm{N})$, axial length of the watershed axis $(\mathrm{L}$ in $\mathrm{km})$, length of the main watercourse $(\mathrm{Lc}$ in $\mathrm{km})$, total 
length of watercourses (Lt in km) and order of watercourses, according to the classification proposed by Strahler. These values served as a basis for the calculation of the morphometric variables through the main methodologies used in applied hydrology, which are presented in Table 2.

Table 2. Morphometric variables, symbology, unit, equation and methodological references used. Tabela 2. Variáveis morfométricas, simbologia, unidade, equação e referências metodológicas utilizadas.

\begin{tabular}{|c|c|c|c|}
\hline Variable & Symbol & Unit & Equation \\
\hline Form Factor & $\mathrm{F}$ & Adim. & $F=\frac{A}{L^{2}}$ \\
\hline Coefficient of Compaction & $\mathrm{Kc}$ & Adim. & $K c=0,28 \frac{P}{\sqrt{A}}$ \\
\hline Circularity Index & $\mathrm{Ci}$ & Adim. & $I c=12,57 \frac{A}{P^{2}}$ \\
\hline Density of Drainage & Dd & $\mathrm{Km} / \mathrm{km}$ & $D d=\frac{L t}{A}$ \\
\hline Density of Rivers & $\mathrm{Rd}$ & Rio $/ \mathrm{km}^{2}$ & $D r=\frac{\bar{N}}{A}$ \\
\hline Coefficient of Maintenance & $\mathrm{Cm}$ & $\mathrm{m}^{2} / \mathrm{m}$ & $C m=\frac{1}{D d} 1000$ \\
\hline Concentration Time & $\mathrm{Ct}$ & Min & $T c=57\left(\frac{L c^{3}}{\Delta h}\right)$ \\
\hline Channel Gradient & $\mathrm{CG}$ & $\%$ & $G c=\frac{h m a ́ x_{L c}}{L c}$ \\
\hline Sinuosity Index & $\mathrm{Si}$ & Adim. & $I_{s}=\frac{L}{d v}$ \\
\hline Reason for Relief & RR & Adim. & $R r=\frac{\Delta h}{L c}$ \\
\hline
\end{tabular}

The results for Drainage Density and River Density were included in the consolidated classifications in the classical literature on applied hydrology (Table 3).

Table 3. Classification of drainage density (Dd) and river density $(\mathrm{Rd})$ of a watershed.

Tabela 3. Classificação de densidade de drenagem (Dd) e densidade de rios (Dr) de uma bacia hidrográfica.

\begin{tabular}{cc}
\hline Density of Drainage & Classification \\
\hline$<0,50$ & Low \\
$0.50-2.00$ & Median \\
$2.01-3.50$ & High \\
$<; 3,50$ & Very High \\
\hline Density of Rivers & Classification \\
\hline$<3$ & Low \\
$7-7$ & Mean \\
$>; 15$ & High \\
\hline
\end{tabular}

The total population in the Jauquara River basin was estimated based on data from the last IBGE census (Brazil, 2010). For that, the data of the rural population (hab) and the area of the municipality $\left(\mathrm{km}^{2}\right)$ of each of the municipalities were used to estimate the rural demographic density (hab $/ \mathrm{km}^{2}$ ), which was multiplied to the area $\left(\mathrm{km}^{2}\right)$ of the river basin belonging to each of them.

\section{RESULTS}

The main source of the Jauquara River is located near the highway MT-160 in the municipality of Porto Estrela / MT, in a region called Coqueiro, where mountainous relief is observed with typical vegetation of preserved cerrado and surroundings of exotic pastures where the livestock of extensive cutting in the modalities creates, recreates and fattens. The mouth of the Jauquara is located in the municipality of Barra do Bugres / MT and its surroundings are mixed between the activities of cattle breeding (rearing and fattening) and sugar cane cultivation for the sugar and alcohol sector. 
The study region is part of the Paraguay River basin, where several communities of quilombos (Vãozinho, Voltinha, Baixius, Retiro, Vaca Morta, Camarinha Cave, Morro Redondo and Juquarinha) are located, settlements of the agrarian reform (Juquara, Liberdade I and II), riverside farmers, traditional family farmers, sugarcane agribusinesses and extensive cattle ranching, agents who benefit from natural resources of the Jauquara. The mouth of the Jauquara River on the Paraguay River confronts the indigenous land of UMUTINA, inserting the exploitation of water resources by indigenous people in the context of the watershed in screen. The basin also presents, in relation to the landscape, exuberant canyons, waterfalls and natural pools being one of the main touristic routes of the municipality of Barra do Bugres (Quilombos circuit).

The area that each municipality occupies in the basin is $322,30 \mathrm{~km}^{2}$ (Barra do Bugres), 336,80 $\mathrm{km}^{2}$ (Nossa Senhora do Livramento), 424,24 km ${ }^{2}$ (Porto Estrela) and 324,69 $\mathrm{km}^{2}$ (Rosário Oeste), with rural population density of $0.860,1.488,1.056$ and 0.946 inhab $/ \mathrm{km}^{2}$, respectively. The total rural population estimated for the basin is of 1,533.00 individuals, being 277 in the municipality of Barra do Bugres, 501 in Nossa Senhora do Livramento, 448 in Porto Estrela and 307 in Rosario Oeste.

The Jauquara river is formed by two main channels, the left channel being the longest and widest and receiving locally the same name of the river, while the right channel receives locally the name of "Juquarinha". The two are close to a geological fracture in the formation of the Serrana Province crossing a deep channel similar to a canyon with rapids and small waterfalls.

With the processing of the DEM in the GIS it was possible to perform the delimitation of the basin and to generate the drainage network, besides the maps of altitude and slope that consequently allowed to obtain the necessary measures for the calculation of the morphometric variables. The delimitation of the Jauquara river basin and the determination of the flow direction are presented in Figure 2 A and B, respectively. In Figure 2 A, the order of the water courses is also highlighted, which are illustrated by different thicknesses of the hydrographic network lines.
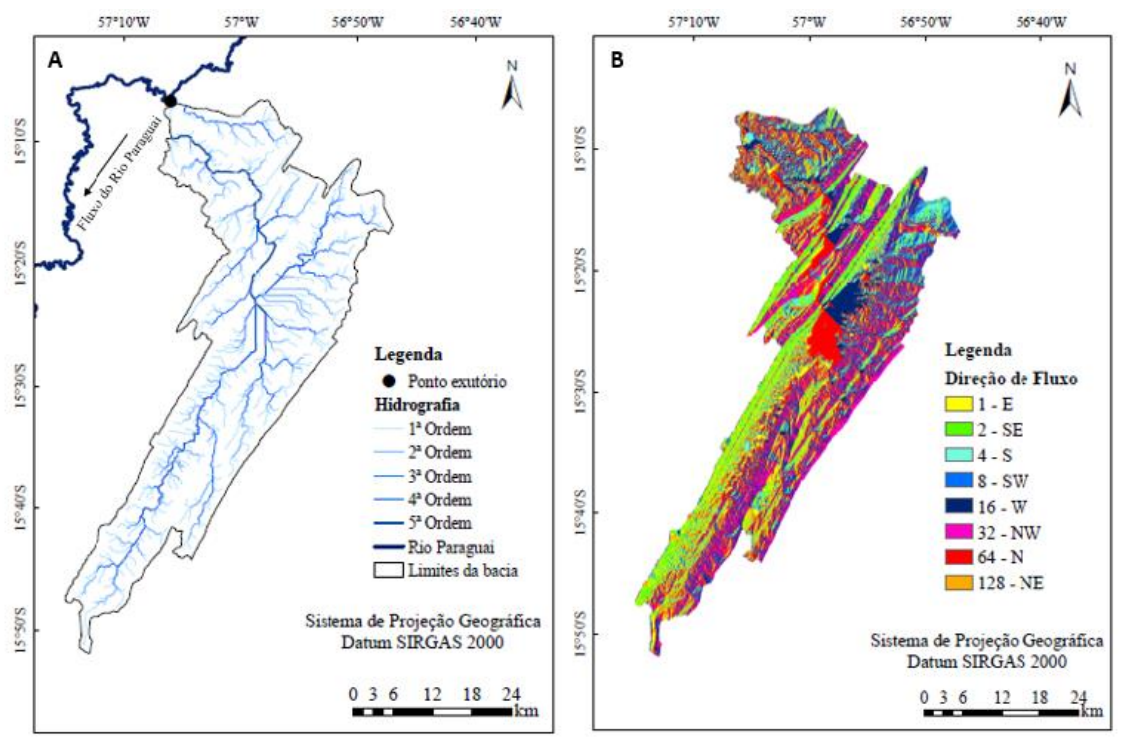

Figure 2. A) Drainage network, outline of the watershed and outflow point of the Jauquara river basin and B) Flow direction of the drainage network.

Figura 2. A) Rede de Drenagem, contorno do divisor de águas e ponto exutório da bacia do rio Jauquara e B)

Direção de fluxo da rede de drenagem.

Table 4 shows the morphometric variables related to geometry, drainage network and relief. For geometry and drainage, the units and value of each evaluated variable are presented and for the relief, the areas and percentage of occurrence of each category are presented. The results of the geometry of the Jauquara river basin are counted through variables that reflect its size and shape; meanwhile, data on drainage reveal information about water courses and drainage network and its main characteristics, whereas relief data evidences the variations of altitude in the basin and the mosaic of predominant soil slopes.

Table 4. Morphometric variables for the Jauquara river basin by category, area and percentage of occurrence. Tabela 4. Variáveis morfométricas para a bacia do rio Jauquara por categoria, área e porcentagem de ocorrência. 


\begin{tabular}{|c|c|c|c|}
\hline & Morphometric Variable & Unit & Value \\
\hline \multirow{5}{*}{ 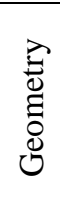 } & Area & $\mathrm{km}^{2}$ & 1408,03 \\
\hline & Perimeter & $\mathrm{Km}$ & 288.43 \\
\hline & Form Factor & Adim. & 0,15 \\
\hline & Coefficient of Compaction & Adim. & 2,15 \\
\hline & Circularity Index & Adim. & 0,21 \\
\hline \multirow{11}{*}{ 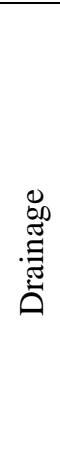 } & Order of watercourses & Adim. & Fifth order \\
\hline & Number of water courses & Courses & 879 \\
\hline & Length of main watercourse & $\mathrm{Km}$ & 110.87 \\
\hline & Total course length & $\mathrm{Km}$ & 1112.66 \\
\hline & Density of Drainage & $\mathrm{km} / \mathrm{km}^{2}$ & 0,79 \\
\hline & Density of Rivers & course $/ \mathrm{km}^{2}$ & 0,62 \\
\hline & Concentration Time & Min & 1009,17 \\
\hline & Coefficient of Maintenance & $\mathrm{m}^{2} / \mathrm{m}$ & 1587.30 \\
\hline & Channel Gradient & $\%$ & 0,07 \\
\hline & Relief Relation & Adim. & 0,74 \\
\hline & Sinuosity Index & Adim. & 1,39 \\
\hline \multirow{13}{*}{$\begin{array}{l}\frac{\mathscr{v}}{\mathscr{Q}} \\
\widetilde{\sim}\end{array}$} & Altitude (m) & Area $\left(\mathbf{k m}^{2}\right)$ & Total Area (\%) \\
\hline & $736-920$ & 4,90 & 0,35 \\
\hline & $552-736$ & 285,91 & 20,30 \\
\hline & $368-552$ & 478,10 & 33,95 \\
\hline & $184-368$ & 452,60 & 32,14 \\
\hline & $0-184$ & 178,35 & 12,66 \\
\hline & Relief/Declivity (\%) & Area $\left(\mathbf{k m}^{2}\right)$ & Total Area (\%) \\
\hline & Plan $(0-3 \%)$ & 268,61 & 19,08 \\
\hline & Soft-Rippled (3-8\%) & 535.75 & 38,05 \\
\hline & Wavy $(8-20 \%)$ & 324,45 & 23,04 \\
\hline & Strong-Wave $(20-45 \%)$ & 210,31 & 14,94 \\
\hline & Mountainous (45-75\%) & 55,18 & 3,92 \\
\hline & Strong-Mountain ( Above 75\%) & 5,78 & 0,47 \\
\hline
\end{tabular}

Figure 3 is a representation of the magnitude of the Jauquara River basin in terms of area and perimeter, i. e., the dimension of circumferences with the same area (Ic) and perimeter $(\mathrm{Kc})$ as the basin.

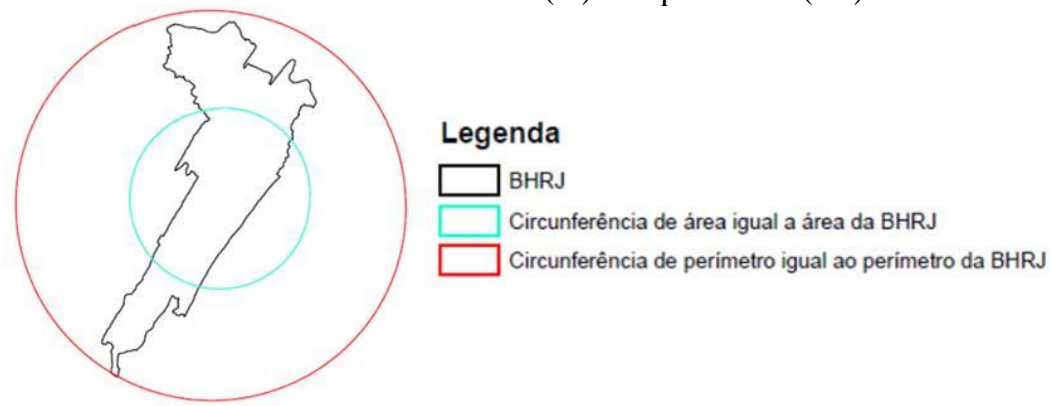

Figure 3. Geometric representation of the circularity index (Ic) and compactness coefficient (Kc) of the Jauquara river watershed.

Figura 3. Representação geométrica do índice de circularidade (Ic) e coeficiente de compacidade (Kc) da bacia do rio Jauquara.

The creation of level curves with spacing of $10 \mathrm{~m}$ allowed the construction of altitude and slope maps, which are presented in Figures 4 A and B, respectively. 

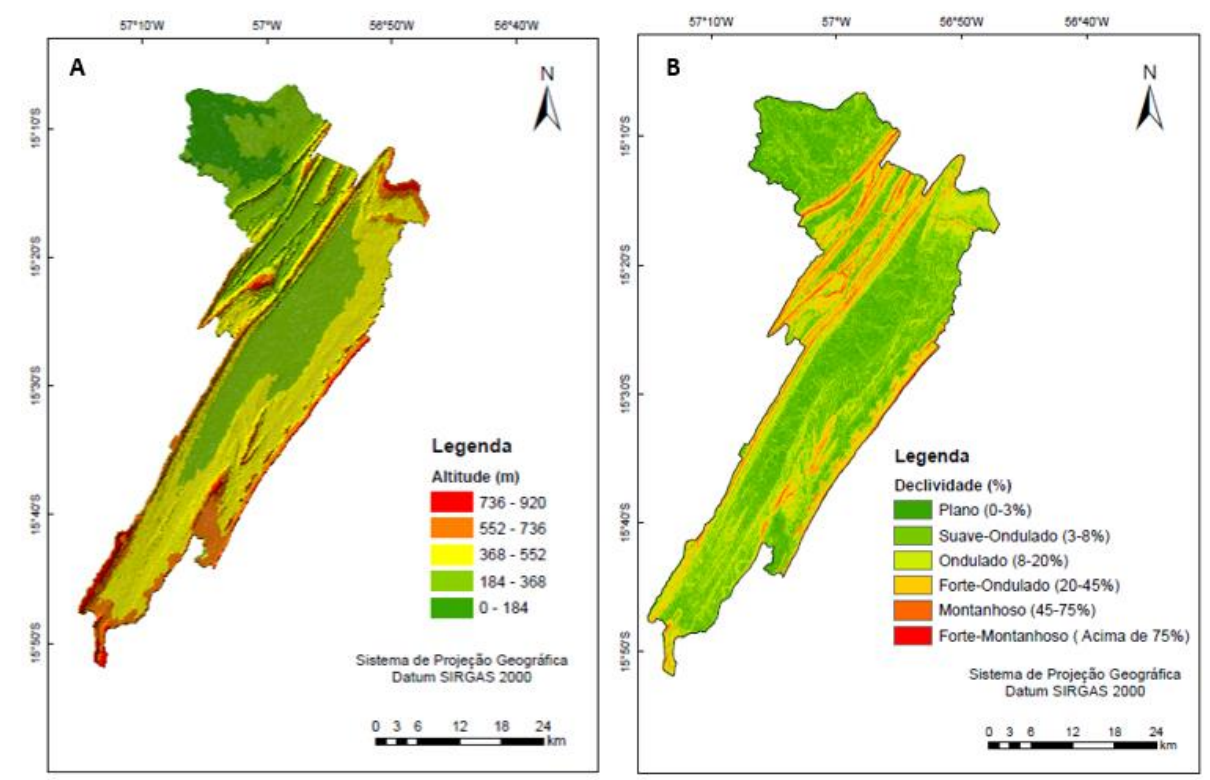

Figure 4. A) Altimetric map of the Jauquara river watershed and B) Map of slope of the Jauquara river watershed. Figura 4. A) Mapa altimétrico da bacia do rio Jauquara e B) Mapa de declividade da bacia do rio Jauquara.

\section{DISCUSSION}

It was verified, through the watershed of the Jauquara River, that there were predominantly diversified agricultural activities between the sugar cane monoculture and the cattle ranching and, to a lesser extent, family farming and livestock activities. The river Jauquara, from the spring to the mouth, supplies several traditional rural communities and still is on the border of the Umutina indigenous land, revealing a cultural, socioeconomic, productive and very rich mosaic. On the other hand, despite the diversity of social groupings, it was observed low rural population density estimated. The low demographic density associated with the diversity of social groups reveals the poor territorial distribution with concentration of lands on large farms as opposed to smallholder farmers with small properties. This socioeconomic arrangement can significantly reflect the management of water resources in the river basin, and may be a source of conflicts of interest.

From Figure 2.A, it is possible to observe that the Jauquara river basin has a very branched drainage network with dendritic format. The water courses tributaries of the main course are configured in parallel, due to the existing mountainous areas. For the Figure 2.B, it is observed that the direction of flow in the tributaries of the main canal of the Jauquara in the south part and west of the watershed run in the Southeastern direction (IF) being this the contrary direction to the flow covered for the Paraguay River, indicated by the arrow in the Figure 2.A.

The size of the Jauquara river basin $\left(A=1,408.03 \mathrm{~km}^{2}\right.$ and $\left.\mathrm{P}=288.43 \mathrm{~km}\right)$ favors the water distribution along the drainage network, so the flow does not remain concentrated in the main channel during flood periods. This fact demonstrates the low propensity of the basin to flash floods, which is a positive factor for the management of water resources. However, as pointed out by Moura (2013), extreme climatic events with precipitation anomalies can trigger peak flows in a short period of time, resulting in sporadic flooding.

Through the morphometric parameters related to the geometry $\left(\mathrm{F}=0.15, \mathrm{~K}_{\mathrm{c}}=2.15, \mathrm{I}_{\mathrm{c}}=0.21\right)$, it is observed that the basin has an elongated shape - which corroborates the shape of the watershed shown in Figure 1. These results reinforce that the basin is little susceptible to the occurrence of floods. Faria et al. (2017) also point out that values for a Coefficient of Compaction greater than 1 are characteristic of elongated watersheds.

The gotten value of the Density of Draining $\left(\mathrm{Dd}=0,79 \mathrm{~km} / \mathrm{km}^{2}\right)$ allowed to classify the basin studied with capacity of medium draining. Basins with greater Dd possess greater capacity of damping the flow (pulse of full), converging to a lesser trend to the overflow (Moura, 2013). The calculated Dd was fit in the medium classroom, what can explain the stories of the local inhabitants on the occurence of water whirlwind in streams Brook and Flagstone, which is affluent of the Juquarinha, main tributary of the Jauquara. The highland with displayed rocky formation, at the same time that it reduces the infiltration of water of rain, it can also contribute to the increase of the superficial draining speed propitiating the occurrence of water whirlwind. One of these events was witnessed in the stream Ribeirão during one of the field visits. Although the general characteristics of the basin do not reflect tendency to floods, the data revealed that some sub-basins present such a characteristic.

The maintenance coefficient obtained $\left(\mathrm{Cm}=1587.30 \mathrm{~m}^{2} / \mathrm{m}\right)$ shows that an area of $1587.30 \mathrm{~m} .^{2}$ is required to maintain $1 \mathrm{~m}$ of drainage channel. This result is considered high when compared with other studies, for example,

FLORESTA, Curitiba, PR, v. 49, n. 2, p. 325-334, abr/jun 2019. 
Batista et al. (2017) found Cm of $32.50 \mathrm{~m}^{2} / \mathrm{m}$ in the Santo Antônio river basin in Goiás. High maintenance coefficients are indicative of flat relief basins (LIMA; FONTES, 2015), which is not the case of the Jauquara river basin, so there may be other not identified factors in this study that are influencing the CM.

The high concentration time obtained $(\mathrm{Tc}=1009,17 \mathrm{~min}$ ) is a positive factor in relation to the floods, because the longer the concentration time, the lower the maximum flood of floods. The Jauquara river basin presents a 5th order drainage network, reinforcing the configuration of the drainage network with a wide hydric distribution between the main channel and its tributaries observed in Figure 2.A. In addition, the Kc (2.15), away from the unit for greater, and the lower $\mathrm{F}(0.15)$ reinforce the high Tc.

The low density of rivers in the Jauquara hydrographic basin was measured in 0,62 canal for $\mathrm{km}^{2}$, i. e., in each area of $1,61 \mathrm{~km}^{2}$ of the basin has a draining canal. This result corroborates the ordering factor of watercourses $\left(5^{\mathrm{a}}\right)$ and their quantity, which are characterized to be branched. According to Gerber et al. (2018), the low Dr reflects the difficulty of raindrops falling to the surface of the ground, quickly finding a channel and flowing through it.

The relief ratio establishes the relationship between altimetric variation and the length of the main channel. In the Jauquara river basin, $\mathrm{Rr}=0.74$ was obtained, a value considered high, which reveals the pattern of relief ranging from smooth wavy to strong mountainous. Souza and Paula (2016) emphasized the importance of $\mathrm{Rr}$ and its direct influence on meteorological and hydrological factors. This observation reveals the need for attention as to the meteorological and hydrological events, since there may be a very diversified manifestation along the basin, due to the relief, with a reflection on the climatic behavior.

The sinuosity index (Is = 1.39) can be classified as intermediate, characteristic of tortuous channels, regular and irregular transitional forms (TEODORO et al., 2007). Lopes et al. (2018), studying the morphometry of a watershed in the semiarid of Pernambuco, found a similar value (Is =1,53). The authors reported that such characteristic indicates the retention time of water in the main channel. Antoneli and Thomaz (2007) point out that this type of intermediate channel favors sediment transport, which should be considered concerning in the Jauquara river watershed, since it is an important tributary of the Upper Paraguay River, one of the main formers of the Pantanal mato-grossense.

The drainage network of the Jauquara river basin presents characteristics of abundance of water volume, a factor of vital importance for the subsistence of the populations that live in the region of study, through the cultivation of agricultural genus, pisciculture, fishing, among others. This aspect, associated with the relief and existence of waterfalls, also shows a potential of energy generation.

From the definition that a perfectly circular basin has $\mathrm{Kc}$ and Ic close to 1, it is observed that the basin has an elongated shape - which corroborates the shape and size of the basin superimposed on the circles of the same area and the same perimeter of the basin presented in Figure 3.

The altitude is related to temperature, precipitation and evapotranspiration, thus, large altimetric variations influence the photosynthetic phenomena and consequently the growth of some crops, in addition to the surface runoff (GEORGIN et al., 2015). In this aspect, the altitude disparity can also be seen in Figure 4.A, where the higher altimetric classes are represented by roughness on a three-dimensional map.

From the perspective of the agricultural aptitude of the lands, the areas that can be favorable to the management of crops correspond to the first two bands of relief (57,13\% of the total area of the basin). As these areas present topography with soft predominance and soft ripples, they have low propensity to erosive processes and can have good mechanization conditions.

The areas whose relief is classified as corrugated correspond to $23.04 \%$ of the total area of the basin and have a range between moderate and strong susceptibility to erosion and impediments to mechanization, therefore they are more suitable for pasture and forestry.

Although these two situations occur, there are a significant percentage of areas in which irregular ripples, morrotes, escarpments and mountain ranges occur (19.34\% of the total area of the basin), whose relief is between the last three ranges, varying between rolling and hilly. There are areas where the native vegetation is observed in a more preserved way.

The balance between soil infiltration and surface runoff and vegetation preservation are essential factors to avoid erosion processes in areas where there is a reduction in water infiltration in soil (SOARES, SOUZA, 2012).

According to the data presented in Table 4, it can be seen that the predominant altitude range is between 368 and $552 \mathrm{~m}$, which corresponds to an area of $478.10 \mathrm{~km}^{2}$, followed by the range between 184 and $368 \mathrm{~m}(452.60$ $\mathrm{km}^{2}$. The raster of the curve level obtained maximum altitude of $920 \mathrm{~m}$ and $150 \mathrm{~m}$ of minim, thus the basin of the river Jauquara presents $770 \mathrm{~m}$ of altimetric amplitude, factor that influences in the variation of the average temperature, in the evapotranspiration and development of the native vegetation.

It was observed that there is a predominance of smooth-wavy and undulated reliefs (3-8\%, 8-20\% slope), which correspond to $38,05 \%$ and $23,04 \%$ of the total basin area, respectively. 


\section{CONCLUSIONS}

- This study allowed the verification of the comprehensiveness of the Jauquara river and to evaluate parameters and morphometric and relief aspects from the input and processing of the data in the GIS environment.

- The morphometric parameters allowed us to characterize the Jauquara river basin as an elongated watershed, which explains the low values for circularity index and form factor, and high coefficient of compactness and concentration time.

- Regarding the aspects related to drainage, the basin has a very branched network, with 5 th order water courses that are distributed in parallel in dendritic format, factors that influence the abundance of the water supply.

- Regarding the parameters and relief maps, despite the predominance of a smooth-wavy and undulating relief with areas better suited to agricultural activities and less susceptible to erosion and soil degradation processes, it was verified that there is a plot of $60.69 \mathrm{~km}^{2}(4.39 \%)$ of the area of the basin that presents relief with more abrupt characteristics (morrotes, scarps and mountains), in which the native vegetation is less exploited due to less aptitude to productive activities.

- The morphometric characterization of the basin made it possible to obtain unpublished information that contributes to the decision making regarding the effective water management in the studied area. However, it is worth mentioning that this information is basic, though fundamental. The continuity of studies of the region, which contemplate factors such as the distribution of rainfall throughout the year, climatic water balance, use and occupation / composition of the soil of the study area; factors that, among others, will contribute to a more concise understanding of the occurrence of phenomena such as floods, erosion and soil permeability, and which will provide subsidies for better soil and water management in this watershed, increasing the guarantees of sustainable rural development and harmony among the residents, meeting their water demands in a satisfactory and balanced way.

\section{ACKNOWLEDGMENTS}

CNPq for granting the scientific initiation grant (PIBIC / UNEMAT-Edital No. 003/2016) and the Foundation for Research Support of the State of Mato Grosso (FAPEMAT) Universal Call 005-2015 Process No. $221509 / 2015$ for granting the tangible resources without which it would not be possible to carry out this work.

\section{REFERENCES}

ANTONELI, V; THOMAZ, EL Characterization of the physical environment of the Arroio Boa Vista basin, Guamiranga-PR. Rev. Pathways of Geography, Uberlândia, v. 8, n. 21, p. 46 - 58, 2007.

BACCI, DC; PATACA, EMP Education for water. Advanced Studies. Sao Paulo, v. 22, n. 63, 2008.

BATISTA, DF; CABRAL, JBP; ROCHA, T.; BARBOSA, GR Morphometric characterization of the drainage basin of the Santo Antônio stream - GO, Geoambiente On-line, v. 1, n. 29, 2017.

BRASIL. BRAZILIAN INSTITUTE OF GEOGRAPHY AND STATISTICS (IBGE) Demographic Census, 2010. Available at: https://cidades.ibge.gov.br/brasil/mt/panorama. Accessed on: 09/22/2018.

ENCINAS, JI; NÓBREGA, RC da; MATRICARDI. EAT Georeferencing of priority areas for biodiversity conservation in the region of the Cerrado Ecomuseum - GO. Encyclopedia biosphere, Centro Científico Conhecer - Goiânia / GO, v. 8, n. 14, p. 2143, 2012.

FARIA, MM; ARAÚJO, WF; GONÇALVES, R .; WANKLER, FL; EVANGELISTA, RAO; SANDER, C. Morphometric characterization of the Igarapé basin Carrapato, Boa Vista, Roraima. Vertices - Campos dos Goytacazes / RJ, v. 19, n. 2, p. 9 - 22, 2017.

GEORGIN, J .; OLIVEIRA, GA; ROSA, ALD Comparative study of morphometric indexes related to floods in the Alto Jacuí and Vacacaí - Vacacaí Mirim - RS watersheds. Electronic Journal in Environmental Management, Education and Technology - Santa Maria / RS, v. 19, n. 2, p. 1357-1364, 2015.

GERBER, D.; PERTILLE, CT; VIEIRA, FS; CORRÊA, BJS; SOUZA, CF Morphometric characterization of the Itajaí River Basin - Santa Catarina. Acta Biológica Catarinense, v. 5, n. 1, p. 72-83, 2018.

GROHMANN, CH; RICCOMINI, C.; STEINER, SS Applications of SRTM elevation models in geomorphology. Rev. Geogr. Academic, v. 2 n. 2, p. 73-83, 2008.

FLORESTA, Curitiba, PR, v. 49, n. 2, p. 325-334, abr/jun 2019. 
KELMAN, J. Water supply to the two largest Brazilian metropolitan regions. Aquatic Procedia: ELSEVIER, v. 5, p. 13-21, 2015.

LEAL, M. S; TONELLO, KC Analysis of morphometry and land use and cover of the Ipaneminha de Baixo stream watershed, Sorocaba / SP.Forest, v. 46, n. 4, p. 439-446, 2016.

LIMA, WP Forest Hydrology applied to Watershed Management. Piracicaba/SP: Graduate School of Agriculture "Luiz de Queiróz", 2008, 245 p.

LIMA, AS; FONTES, AL Study of morphometric parameters of the Jacarecica River sub-basin (SE). Revista Inter Espaço, Grajaú / MA v. 1, n. 3, p. 203 - 221, 2015.

LOPES, I .; LEAL, BG; RAMOS, CMC Morphometric characterization of the basin in the semi-arid region of Pernambuco using SRTM data in free software. Journal of Hyperspectral Remote Sensing, v. 8, n. single, p. 3140, 2018.

MOURA, CA Evaluation of flood tendency in the watersheds of the city of Caraguatatuba (SP), Revista de Geografia (UFPE), v. 30, n. 2, p. 123 - 138, 2013.

PESSOA, SPM; GALVANIN, EAS; NEVES, SMAS Mapping and use of forest occupation in the Paraguay River - Barra do Bugres / MT. Brazilian Journal of Cartography, São Paulo / SP, v. 6, n. 66, p. 1295-1303, 2014.

PORTO, MFA; PORTO, RL Watershed management. Advanced Studies, São Paulo, v. 22, n. 63, 2008.

RAMALHO FILHO, A.; BEEK, KJ Assessment system for agricultural land suitability. 3 ed. Rio de Janeiro: Embrapa CNPS, 1995. 65 p.

SOARES, J MRG; SOUZA, JL M de. Morphometric analysis of the Rio Pequeno in São José dos Pinhais (PR). Geography Magazine - Londrina / PR, v. 21, n. 1, p. 19-36, 2012.

NEPHEW, T. A; OLIVEIRA, PT S; RODRIGUES, DB B; AYRES, FM Automatic delimitation of watersheds using SRTM data Agricultural Engineering - Jaboticabal / SP, v. 30, n. 1, p. 46-57, 2010.

SOUZA, AP de; MOTA, LL; ZAMADEI, T.; MARTIM CC; ALMEIDA, FT de; PAULINO, J. Climatic characterization and climatological water balance in the state of Mato Grosso. Native - Sinop / MT, v.1, n. 1, p. 34 - 43, 2013.

SOUSA, FRC of; PAULA, DP of. Morphometric characterization of the Tapuio river basin (Ceará-Brazil). REGNE, v. 2, n. Special, p. 555-564, 2016.

THEODODO, VLI; TEIXIERA, D; COSTA, DJL; FULLER, BB The concept of hydrographic basin and the importance of the morphometric characterization to the understanding of local environmental dynamics. REVISTA UNIARA, n. 20, p. 136-146, 2007. 